\title{
Accrual Earnings Management, Social Responsibility and Corporate Performance
}

\author{
Na Zhang \\ Wuhan University of Technology School of Management \\ 2388867591@qq.com
}

\begin{abstract}
Keywords: Accrual earnings management; Social responsibility; Future operating performance; Management
\end{abstract}

\begin{abstract}
This paper investigates the influence of accrual earnings management on the future operating performance of the company, and the regulatory effect of social responsibility on accrual earnings management and future operating performance of the company. The conclusions are as follows: accrual earnings management will produce positive impact on short-term business performance, and produce negative impact on long-term business performance. At the same time, the fulfillment of social responsibility has a significant positive correlation with the company's future operating performance. After taking into account the regulatory role of social responsibility, it will reduce the positive effect of accrued earnings management on short-term business performance. The conclusion of this paper provides empirical evidence for the role of social responsibility in the micro-mechanism of the company, and also provides some reference for the perfection of accounting standards and supervision mechanism.
\end{abstract}

CLC number F276.6 Document identification code: A

\section{Introduction}

In the past research, the impact of earnings management on the company's operating performance is still controversial, whether it is effective or opportunistic, or earnings management to improve the company's operating performance or reduce the company's operating performance? Scholars, represented by Healy (1985), argue that corporate management will manipulate surpluses for their own benefit to maximize pay [1]. In China, the degree of marketization is not high, the rule of law is weak in the environment, the earnings management is easier to become a means of self-management. Some scholars find that there is a significant negative correlation between earnings management and firm performance through empirical tests (Roychowdhury, 2006; C. Cai et al., 2013) [2,3]. They found that the earnings management of opportunistic effects leads to excessive investment behavior, and damages corporate value. However, some studies have found that management will manipulate earnings for the purpose of effective profit smoothing, and moderate earnings management will give the market good news for the future development of the company, help to enhance investor confidence and improve the performance of the company (H.J. Zhu, 2004; Y.Y. Chen, 2010) [4,5]. It can be seen that the relationship between earnings management and the company's future operating performance is not clear, and few scholars have studied the effect of accrual earnings management on short-term and long-term operating performance, which is one of the key issues in this paper.

Scholars have found that the institutional environment is an important factor affecting the company's accrual earnings management. The existing literatures mainly focus on the influence of the regional marketization level, the degree of government intervention, the political connection, the independence of the audit committee and the degree of ownership concentration on the accrual earnings management (Y.B. Jiang and Yan Ting, 2012; Y.Z. Liu et al., 2013; S.H. Wang and Y. Li, 2012; Z.Q. Yang and H. Wang, 2014) $[6,7,8,9]$. There are few studies on the implementation of corporate social responsibility, especially from the perspective of stakeholders. In general, stakeholders can change their opportunistic behavior by resisting and lobbying for abuse of management power (Rowley \& Berman, 2000) [10]. This indirect control also includes: the 
collective action of employees, customer complaints to the company, the upstream and downstream partners of the abandoned, regulatory department of litigation and so on. In this context, the implementation of corporate social responsibility can play a role in internal governance, urging the company in accordance with established standards for legitimate business, the better control of the controlling shareholder "interests encroachment" behavior, safeguard the interests of small shareholders, and achieve the company's sustainable development (Y. Zhao and Q.G. Feng, 2014) [11]. In view of this, how to base on the Chinese system environment, to seek the relationship between social responsibility and corporate performance, to explore the social responsibility on the accrual of earnings management and the company's operating performance of the regulatory role will have very important significance.

This paper focuses on two specific issues: First, the listed company's earnings management behavior will affect the company's short-term and long-term business performance? The second is to consider the role of social responsibility, the accrual of earnings management on the company's operating performance will be how the changes? Based on a sample of A-share listed companies in China's Shanghai and Shenzhen stock markets in 2010-2012, this paper examines the impact of accrual earnings management on future operating performance and the adjustment of social responsibility to accrual earnings management and future operating results, in order to enrich the academic literature in the field of accrual earnings management and provide empirical evidence for the role of corporate social responsibility in the micro-mechanism of the company.

\section{The Theoretical Analysis and Research Assumptions}

At present, the view of explaining earnings management is information transmission view, effective contract view and opportunism behavior view. X.D. Yang et al. (2015) found that the management of the company will convey the positive signal of the future performance of the company to the market through moderate earnings management behavior and improve the connotation of accounting earnings information, thus enhancing investor confidence and promoting the steady and healthy development of the company [12]. The effective contractual view holds that the earnings management of the enterprise management authorities will reduce the potential losses caused by the conflict of interest among the various stakeholders, so as to reduce the contract cost and improve the operating performance of the enterprise. X.J. Zhang (2004), W.Q. Yuan et al. (2014) have also confirmed this view [13,14]. There is also literature supporting the opportunistic behavioral view of earnings management, which suggests that managers seek to maximize their utility by using accounting options and accounting to gloss over their financial statements to meet the expectations of the company's performance growth (Z.C. Wu, 2009) [15].

Although the company's management will smooth the reporting surplus for different accounting periods through earnings management to stimulate the growth of short-term corporate performance, the company's actual surplus does not change. The profit manipulation of accrued earnings management only changes the actual earnings in different accounting period, while the reversal of the accrual of manipulative accruals will result in the company's performance within a long period of decline. J.X. Geng et al. (2011) found that the accrual accruals have the characteristics of reversal through the empirical research on the private placement of controlled shares, and the early improvement of the company's operating performance through accrual earnings management will reduce the value of the enterprise in the future [16]. Based on the above analysis, this paper proposes the following assumptions:

Assumption 1: Accrual earnings management will have a positive impact on the company's short-term operating results and adversely affect the company's long-term operating results.

According to the Stakeholder Theory, scholars such as Freeman (1984) argue that the fulfillment of corporate social responsibility is to meet the demands of various stakeholders, which will promote the sustainable management of enterprises to a certain extent, to bring good business performance [17]. Cornell and Shapiro (1987) illustrate this relationship from the perspective of stakeholder claims on corporate resources [18]. They point out that if firms fail to meet stakeholder expectations, they may cause market panic and increase risk premiums, which in turn affect the 
firm's financial position. Conversely, if firms meet stakeholder expectations, they will reduce their stealth contracts cost, improve the company's financial performance. In addition, stakeholder instrumentation (Donaldson and Preston, 1995) argues that there is a reciprocal relationship between the stakeholders and the managers of the enterprise, and the fulfillment of social responsibility promotes the improvement of the business performance [19]. Some scholars from the transaction cost theory and resource-based theory point of view confirmed this view. D.W. Su and X.X. He (2011) argue that the positive social responsibility of enterprises will increase their social reputation, reduce information asymmetry and transaction costs, and increase the financial performance of enterprises [20]. Resource-based theory holds that the implementation of corporate social responsibility is an intangible assets, as a way to improve business performance. The positive correlation between social responsibility and business performance has also been verified by the empirical results of domestic scholars (Chen, 2009; B.J. Yang, 2012) [21,22].

At the same time, Shleifer (2004) argued that the implementation of corporate social responsibility would increase corporate transparency and reduce the motivation for earnings management [23]. Subsequently, Shen and Chih (2005) confirmed this view through empirical studies that companies not only focus on the current and short-term gains, but also focus on nurturing the future relationship with stakeholders, to seek the sustainable development of enterprises [24]. Domestic scholars such as X.Z. Deng et al. (2011) found that corporate social responsibility can reduce the performance of corporate management abuse of information superiority, reduce the degree of information asymmetry, thereby increasing corporate transparency [25], which to some extent also shows that social responsibility can restrain the earnings management behavior of the company and improve the company's operating performance. On the one hand, the implementation of corporate social responsibility is to safeguard the interests of more small and medium investors, to achieve sustainable development of enterprises, and earnings management is a short-term interest-driven management behavior to harm the long-term interests of the cost of business, so that the major shareholders or controlling shareholders directly benefit. These two acts are more interaction and mutual restraint, which means that corporate social responsibility will inhibit the earnings management of the company's future operating performance of the negative impact of the spread. On the other hand, under the natural restraint of morality and law, the fulfillment of corporate social responsibility needs to disclose more detailed and informative financial announcements, which in itself convey the "good news" to the market, to a certain extent reduce the motivation of corporate earnings management. Based on the above analysis, this paper proposes the following assumptions:

Assumption 2: There is a significant positive correlation between the performance of corporate social responsibility and corporate performance.

Assumption 3: The fulfillment of social responsibility can restrain the positive correlation between accrual earnings management and corporate operating performance.

\section{Research and Design}

Sample Selection And Data Sources. According to F.S. Wang et al. (2014), this paper needs to use the data of the base period for the next three years to measure the future operating performance of the company. The latest financial statement data is 2015. Therefore, this paper takes the A-share listed companies in Shanghai and Shenzhen in 2010-2012 as the base period samples. (1) In accordance with the SFC 2012 industry classification, to exclude the financial sector sample; (2) to exclude companies that have been specially treated during the study period; (3) to exclude companies that cannot fully access the relevant data. According to the principle of data selection, this paper obtains the unbalanced panel data of 1820 A-share listed companies from 2010 to 2012, and the total number of samples is 4238 . In this paper, unbalanced panel data can be expanded to a certain extent, the sample size of empirical testing to improve the credibility of the test results.

Listed companies are from the CSMAR database and the WIND database. Individual missing data are obtained manually by referring to the annual reports of listed companies. In addition, in order to eliminate the impact of extreme values, this paper uses the stata12.0 to carry on the 
Winsorize processing on the financial data $1 \%$ before and after the year, and use stata12.0 data processing and analysis software to carry on the empirical test to the regression model.

Variable Definition. Company performance $\left(\mathrm{AdjCFO}_{t+n}\right)$ : This paper draws on F.S. Wang et al. (2014), using the net operating cash flow after the beginning of the total assets as a measure of the company's future business performance [26]. In addition, in order to reflect the relative performance of the company's operating performance in the same industry, the $\mathrm{CFO}_{t}$ of the sample company is reduced by the median of the same company's $\mathrm{CFO}_{t}$ in the same year, and the measured variable of the future operating performance of the company $\operatorname{AdjCFO}_{t+n}(n=1,2,3 ; t+1 、 t+2 、 t+3$ denote the first, second, and third years after the base period, respectively).

Earnings Management (DA): In this paper, we use the modified Jones model to calculate the absolute value of discretionary accruals as a measure of earnings management. Specific calculation is as follows:

$$
\begin{aligned}
& \frac{\mathrm{TAC}_{\mathrm{i}, \mathrm{t}}}{\mathrm{TA}_{\mathrm{i}, \mathrm{t}-1}}=\mathrm{a}_{0}+\mathrm{a}_{1} * \frac{1}{\mathrm{TA}_{\mathrm{i}, \mathrm{t}-1}}+\mathrm{a}_{2} * \frac{\Delta \mathrm{REV}_{\mathrm{i}, \mathrm{t}}}{\mathrm{TA}_{\mathrm{i}, \mathrm{t}-1}}+\mathrm{a}_{3} * \frac{\mathrm{PPE}_{\mathrm{i}, \mathrm{t}}}{\mathrm{TA}_{\mathrm{i}, \mathrm{t}-1}}+\varepsilon_{\mathrm{i}, \mathrm{t}} \\
& \frac{\mathrm{NDA}_{\mathrm{i}, \mathrm{t}}}{\mathrm{TA}_{\mathrm{i}, \mathrm{t}-1}}=\mathrm{a}_{0}+\mathrm{a}_{1} * \frac{1}{\mathrm{TA}_{\mathrm{i}, \mathrm{t}-1}}+\mathrm{a}_{2} * \frac{\Delta \mathrm{REV}_{\mathrm{i}, \mathrm{t}}-\Delta \mathrm{REC}_{\mathrm{i}, \mathrm{t}}}{\mathrm{TA}_{\mathrm{i}, \mathrm{t}-1}}+\mathrm{a}_{3} * \frac{\mathrm{PPE}_{\mathrm{i}, \mathrm{t}}}{\mathrm{TA}_{\mathrm{i}, \mathrm{t}-1}}+\varepsilon_{\mathrm{i}, \mathrm{t}}
\end{aligned}
$$

According to the Eq.1, the data of the sub-industry are returned after years, the regression coefficient is brought into the Eq. 2 to obtain the non-accrual accrual profit $\mathrm{NDA}_{\mathrm{i}, \mathrm{t}} \cdot \mathrm{TAC}_{\mathrm{i}, \mathrm{t}}$ is the total profit accrued in period $\mathrm{t}$ of $\mathrm{i} ; \mathrm{TA}_{\mathrm{i}, \mathrm{t}-1}$ is the total assets at the end of period $\mathrm{t}-1$ of company $\mathrm{i}$; $\triangle \mathrm{REV}_{\mathrm{i}, \mathrm{t}}$ is the difference between the operating income and the operating income of the previous period; $\Delta \mathrm{REC}_{\mathrm{i}, \mathrm{t}}$ is the difference between the receivables at the end of period $\mathrm{t}$ and the accounts receivable at the end of last period; $P P E_{i, t}$ is the value of fixed asset at period $t ; N_{i, t}$ is the non-accrual accrual of firm i for period $t$.

$$
\mathrm{DA}_{\mathrm{i}, \mathrm{t}}=\left|\frac{\mathrm{TAC}_{\mathrm{i}, \mathrm{t}}}{\mathrm{TA}_{\mathrm{i}, \mathrm{t}-1}}-\frac{\mathrm{NDA}_{\mathrm{i}, \mathrm{t}}}{\mathrm{TA}_{\mathrm{i}, \mathrm{t}-1}}\right|
$$

According to Eq.3, the absolute value $\mathrm{DA}_{\mathrm{i}, \mathrm{t}}$ of discretionary accruals of listed companies in each sample is calculated, which is the measurement variable of company's earnings management degree.

Social Responsibility (CSR): This paper refers to the study of Y.Y. Zhou and C. Lin (2015), to build a comprehensive indicator of social responsibility measurement [27], namely: corporate social responsibility $=($ government responsibility + investor responsibility + employee responsibility + supplier responsibility + social responsibility) - negative responsibility

This paper introduces the factors that may influence the degree of earnings management of the firm as control variables (Roychowdhury, 2006; Zang, 2012) [28], which are: earnings per share (EPS), earnings per share at the end of the year; company growth (GROWTH), operating income growth rate; asset-liability ratio (LEV); equity concentration (TOP1), the proportion of the largest shareholder.

Regression Model. In order to test Assumption 1, we study the correlation between earnings management and future operating performance of the company. This study uses Gunny regression model to test the regression model:

$$
\begin{aligned}
\text { AdjCFO }_{i, t+n} & \\
& =\alpha_{0}+\alpha_{1} \mathrm{DA}_{i, \mathrm{t}}++\alpha_{2} \mathrm{EPS}_{\mathrm{i}, \mathrm{t}}+\alpha_{3} \mathrm{GROWTH}_{\mathrm{i}, \mathrm{t}}+\alpha_{4} \mathrm{LEV}_{\mathrm{i}, \mathrm{t}}+\alpha_{5} \mathrm{TOP}_{\mathrm{i}, \mathrm{t}} \\
& +\varepsilon_{\mathrm{i}, \mathrm{t}}
\end{aligned}
$$


In order to examine Assumption 2 and Assumption 3, we examine the influence of social responsibility on future business performance and the intermediary relationship of social responsibility. The regression model constructed in this paper is:

$$
\begin{aligned}
\operatorname{AdjCFO}_{\mathrm{i}, \mathrm{t}+\mathrm{n}} & =\alpha_{0}+\alpha_{1} \mathrm{CSR}_{\mathrm{i}, \mathrm{t}}+\alpha_{2} \mathrm{EPS}_{\mathrm{i}, \mathrm{t}}+\alpha_{3} \mathrm{GROWTH}_{\mathrm{i}, \mathrm{t}}+\alpha_{4} \mathrm{LEV}_{\mathrm{i}, \mathrm{t}}+\alpha_{5} \mathrm{TOP} 1_{\mathrm{i}, \mathrm{t}} \\
& +\varepsilon_{\mathrm{i}, \mathrm{t}} \\
\operatorname{AdjCFO}_{\mathrm{i}, \mathrm{t}+\mathrm{n}} & \\
& =\alpha_{0}+\alpha_{1} \mathrm{DA}_{\mathrm{i}, \mathrm{t}}+\alpha_{2} \mathrm{CSR}_{\mathrm{i}, \mathrm{t}}+\alpha_{3}\left(\mathrm{DA}_{\mathrm{i}, \mathrm{t}} \times \mathrm{CSR}_{\mathrm{i}, \mathrm{t}}\right)+\alpha_{4} \mathrm{EPS}_{\mathrm{i}, \mathrm{t}}+\alpha_{5} \mathrm{GROWTH}_{\mathrm{i}, \mathrm{t}} \\
& +\alpha_{6} \mathrm{LEV}_{\mathrm{i}, \mathrm{t}}+\alpha_{7} \mathrm{TOP}_{\mathrm{i}, \mathrm{t}}+\varepsilon_{\mathrm{i}, \mathrm{t}}
\end{aligned}
$$

\section{The Empirical Results And Analysis}

Descriptive Statistical Analysis. Table 1 shows the descriptive statistics for the primary variables. It can be seen that the average value of social responsibility (CSR) is 0.8067 , the maximum value is 1.2 , and the minimum value is 0.1875 , which shows that there are differences in the fulfillment degree of CSR in different enterprises in China. The conclusion is in line with the development of Chinese enterprises. While the average of accrued earnings management (DA) is 0.0865 and the median is 0.0631 , which indicates that there is a phenomenon of accrued earnings management in Chinese listed companies. To eliminate the impact of extreme values, this paper uses stata12.0 on the financial data before and after the annual sub-1\% level of Winsorize processing.

Table 1 Sample descriptive statistics

\begin{tabular}{c|c|c|c|c|c}
\hline Variables & Mean & $\begin{array}{c}\text { Standard } \\
\text { Deviation }\end{array}$ & Median & Min & Max \\
\hline CFO & 0.0092 & 0.0873 & 0.0093 & -0.2673 & 0.2886 \\
\hline DA & 0.0865 & 0.08255 & 0.0631 & 0.0009 & 0.5719 \\
\hline CSR & 0.8067 & 0.1949 & 0.8695 & 0.1875 & 1.200 \\
\hline DA $\times$ CSR & 0.0690 & 0.06914 & 0.04830 & 0.0002 & 0.5746 \\
\hline EPS & 0.3838 & 0.4387 & 0.3076 & -0.9 & 2.36 \\
\hline GROWTH & 0.1658 & 0.4321 & 0.1126 & -0.7585 & 3.5170 \\
\hline LEV & 0.3853 & 0.2161 & 0.3768 & 0.0227 & 0.9465 \\
\hline TOP1 & 0.3671 & 0.1513 & 0.3517 & 0.0850 & 0.7510 \\
\hline
\end{tabular}

Table 2 shows the results of the correlation analysis of the main variables. From Table 2, we can see that the correlation coefficient of the main research variables is not high, indicating that there is no multiple line between variables, that is, the empirical results are credible. 
Table 2 Correlation analysis results

\begin{tabular}{c|c|c|c|c|c|c|c|c}
\hline & CFO & DA & CSR & DA $\times$ CSR & EPS & $\begin{array}{c}\text { GROWT } \\
\text { H }\end{array}$ & LEV & TOP1 \\
\hline CFO & 1 & & & & & & & \\
\hline DA & $0.1271 * * *$ & 1 & & & & & & \\
\hline CSR & $0.1247 * * *$ & $-0.051 * * *$ & 1 & & & & & \\
\hline DA $\times$ CSR & $0.1587 * * *$ & $0.9339 * * *$ & $0.2129 * * *$ & 1 & & & & \\
\hline EPS & $0.1645 * * *$ & $0.1872 * * *$ & 0.0045 & $0.1820 * * *$ & 1 & & & \\
\hline GROWTH & 0.0195 & $0.1130 * * *$ & $-0.0310^{* *}$ & $0.1019 * * *$ & $0.1766^{* * *}$ & 1 & & \\
\hline LEV & 0.0216 & 0.0152 & $0.1160 * * *$ & $0.0437 * * *$ & $-0.1954 * * *$ & $0.0543 * * *$ & 1 & \\
\hline TOP1 & $0.0812 * * *$ & 0.0172 & $0.0803 * * *$ & $0.0489 * * *$ & $0.1280^{* * *}$ & 0.0119 & 0.0064 & 1 \\
\hline
\end{tabular}

Note: The values in brackets are $\mathrm{t}$ values, $*$ for $\mathrm{p}<0.1, * *$ for $\mathrm{p}<0.05, * * *$ for $\mathrm{p}<0.01$.

Relationship between Earnings Management and Future Operating Performance of the Company. Table 3 shows the regression results of the relationship between earnings management and future operating performance. From Table 3, the coefficient of DA (0.0357) in the $t+1$ year is positive, and is significant at the $10 \%$ level, the coefficients of DA in $t+2$ years and $t+3$ years become smaller gradually, but not significant. This indicates that the management of the company used the accrued earnings management to manipulate the surplus. In the short term (such as the year $t+1$ ), the short-term growth of the company's operating performance was confirmed, which proves that the accrual earnings management has a positive effect on the short-term business performance. However, in the subsequent years $t+2$ years and $t+3$ years of gradual decline in operating results, although not significant, there are reasons to believe that accrual earnings management of the company's long-term performance has a negative impact, but the impact is weak. These results support the assumption 1.

Table 3 Earnings management and future operating performance

\begin{tabular}{c|c|c|c}
\hline \multirow{2}{*}{ variable } & \multicolumn{3}{|c}{$(1)$} \\
\cline { 2 - 4 } & $\mathrm{AdjCFO}_{t+1}$ & $\mathrm{AdjCFO}_{t+2}$ & $\mathrm{AdjCFO}_{t+3}$ \\
\hline \multirow{2}{*}{$\mathrm{DA}$} & $0.0357 *$ & 0.00428 & -0.000859 \\
& $(1.71)$ & $(0.20)$ & $(-0.04)$ \\
\hline \multirow{2}{*}{ EPS } & $-0.0197 * * *$ & 0.00151 & -0.00328 \\
& $(-3.27)$ & $(0.25)$ & $(-0.51)$ \\
\hline \multirow{2}{*}{ GROWTH } & 0.00169 & -0.00315 & 0.00205 \\
& $(0.50)$ & $(-0.92)$ & $(0.57)$ \\
\hline \multirow{2}{*}{ LEV } & 0.000450 & 0.0159 & 0.0173 \\
& $(0.02)$ & $(0.69)$ & $(0.72)$ \\
\hline \multirow{2}{*}{ TOP1 } & 0.0397 & 0.0644 & -0.0539 \\
& $(0.71)$ & $(1.14)$ & $(-0.90)$ \\
\hline cons & -0.00131 & -0.0246 & 0.0171 \\
\hline & $(-0.06)$ & $(-1.08)$ & $(0.72)$ \\
\hline N & 4238 & 4238 & 4238 \\
\hline adj. R2 & $1.05 \%$ & $1.28 \%$ & $1.07 \%$ \\
\hline
\end{tabular}

Note: The values in brackets are $\mathrm{t}$ values, * for $\mathrm{p}<0.1, * *$ for $\mathrm{p}<0.05$, *** for $\mathrm{p}<0.01$.

Relationship between Earnings Management, Social Responsibility and Future Business Performance. It can be seen from the above test results, the relationship between DA and 
$\mathrm{AdjCFO}_{t+2} 、 \mathrm{AdjCFO}_{t+3}$ is not significant, so the main base after the first year of the company's operating performance $\mathrm{AdjCFO}_{t+1}$ as the explanatory variables. Table 4 below shows the regression results of the relationship between earnings management, social responsibility and future operating performance. Results (2), there is a significant positive correlation between social responsibility (CSR) and the future operating performance of the company, indicating that the fulfillment of social responsibility has a positive impact on the company's future business performance. It can be seen that the companies that fulfill their social responsibilities will take into account the interests of all stakeholders and improve the company's future business performance. This result supports the assumption 2.

Results (3) show significant positive correlation between accrued earnings management (DA), social responsibility (CSR) and future operating performance. The regression coefficient $(-0.287)$ of the two crossings (DA $\times$ CSR) is significantly negative at the level of $1 \%$, indicating that the implementation of social responsibility can inhibit the positive correlation between the accrual earnings management and the future operating performance of the company. This result supports the assumption 3 .

Table 4 Relationship between earnings management, social responsibility and future operating performance of the Company

\begin{tabular}{c|c|c}
\hline \multirow{2}{*}{ variable } & $(2)$ & $(3)$ \\
\cline { 2 - 3 } & $\mathrm{AdjCFO}_{t+1}$ & $\mathrm{AdjCFO}_{t+1}$ \\
\hline \multirow{2}{*}{$\mathrm{DA}$} & & $\begin{array}{c}0.266^{* * *} \\
(3.31)\end{array}$ \\
\hline \multirow{2}{*}{ CSR } & $\begin{array}{c}0.0255^{*} \\
(1.72)\end{array}$ & $\begin{array}{c}0.0544 * * * \\
(3.09)\end{array}$ \\
\hline \multirow{2}{*}{ DA $\times$ CSR } & & $-0.287 * * *$ \\
& & $(-2.96)$ \\
\hline \multirow{2}{*}{ EPS } & $-0.0193 * * *$ & $-0.0209 * * *$ \\
& $(-3.21)$ & $(-3.47)$ \\
\hline \multirow{2}{*}{ GROWTH } & 0.00239 & 0.00174 \\
& $(0.71)$ & $(0.52)$ \\
\hline \multirow{2}{*}{ LEV } & 0.00324 & 0.00239 \\
& $(0.14)$ & $(0.11)$ \\
\hline \multirow{2}{*}{ TOP1 } & 0.0361 & 0.0393 \\
& $(0.65)$ & $(0.70)$ \\
\hline cons & -0.0188 & $-0.0454 *$ \\
\hline & $(-0.75)$ & $(-1.73)$ \\
\hline $\mathrm{N}$ & 4238 & 4238 \\
\hline adj. R2 & $0.21 \%$ & $1.06 \%$ \\
\hline
\end{tabular}

Note: The values in brackets are $\mathrm{t}$ values, * for $\mathrm{p}<0.1, * *$ for $\mathrm{p}<0.05$, *** for $\mathrm{p}<0.01$.

Robustness Test. In order to test the reliability of the results of the study, the following robustness tests (limited to space, unlisted test results) are performed: using the extended Jones model to estimate manipulative accruals (DA) for regression testing; using the Tobin $\mathrm{Q}$ value to control the impact of the growth opportunities of the firm and to enter the model test. The results of empirical tests of different robustness tests show no substantial change from the previous ones, and the results are credible and robust. 


\section{Conclusion}

Based on the sample of A-share listed companies in Shanghai and Shenzhen in 2010-2012, this paper studies the impact of accrual earnings management on future operating performance of the company and the adjustment of social responsibility to accrual earnings management and future operating performance of the company. The following conclusions: The accrual earnings management will have a positive effect on the short-term operating performance of the company and have a negative impact on the long-term business performance. At the same time, the fulfillment of social responsibility will have a significant positive correlation with the future operating performance of the company. Considering the regulatory role of social responsibility, it will reduce the positive impact of accrued earnings management on short-term business performance.

This empirical evidence shows that social responsibility plays a negative role in the impact of accrual earnings management on short-term operating performance of the company, and social responsibility will inhibit the occurrence of corporate earnings management behavior. This shows that the fulfillment of social responsibility can contribute to the sound development and effective improvement of corporate governance, so that the management authorities will give due consideration to the interests of small and medium investors and ensure the interests of all the stakeholders in corporate decision-making. This kind of negative-phase regulation is also an important micro-mechanism for fulfilling social responsibility to improve corporate governance and improve the company's operating performance. With the increasing attention to social responsibility, in order to achieve sustained and good development, the company should strengthen the fulfillment of social responsibility, disclose the relevant information on corporate social responsibility in a timely and detailed manner, and implement the social responsibility in a timely manner. The results of this study not only enrich the academic literature in the field of accrual earnings management, but also provide empirical evidence for the microcosmic mechanism of corporate social responsibility, and also have some reference for the perfection of accounting standards and supervision mechanism.

Of course, this article still has some limitations: First, the paper chooses adjusted net operating cash flow as a measure of the company's operating performance, which includes contingent non-recurring cash flows, cash spent to maintain business survival. It is difficult to be controlled by the management, but sometimes cannot fully reflect the real situation of production and operation. Therefore, it is also necessary to explore the impact of earnings management on different indicators of the company's operating performance. Second, this article only concerned about accrued earnings management and the company's future business performance relationship, did not explore the real earnings management and non-recurring gains and losses on the company's future business performance impact. The above problems also constitute the direction of future research.

\section{References}

[1] P. Healy, The Effect of Bonus Schemes on Accounting Decisions, Journal of Accounting and Economics, 1985, 7(1-3): 85-107.

[2] S. Roychowdhury, Earnings management through Real Activities Manipulation, Journal of Accounting and Economics, 2006(42): 335-370.

[3] C. Cai, M. Li and H. He, Straints, IPO Earnings Management and Corporate Performance Research Based on Accrual Earnings Management and Real Earnings Management, Accounting Research, 2013, 10: 35-42 + 96(In Chinese).

[4] H.J. Zhu, Analysis of senior managerial personnel turnover and operating performance, Chinese Journal of Economic Statistics, 2004, 04: 82-92(In Chinese).

[5] Y.Y. Chen, Investment real estate in the earnings management of the spatial analysis, Accountants, 2010,03: 50-51(In Chinese). 
[6] Y.B. Jiang and T. Yan, Research on the Influence of Institutional Environment on the Execution of Accounting Standards, Accounting Research, 2012, 04: 69-78 + 95(In Chinese).

[7] Y.Z. Liu, D.L. Zhang and D.P. Tang, Political Degree, Political Linkage and Earnings Management: An Empirical Study Based on Small and Medium Private Listed Companies in Shenzhen, Auditing and Economic Research, 2013, 02: 49-58(In Chinese).

[8] S.H. Wang and Y. Li, Management Intervention, Audit Committee Independence and Earnings Management, Auditing Research, 2012, 04: 68-75(In Chinese).

[9] Z.Q. Yang and H. Wang, Internal Compensation Gap, Equity Concentration and Earnings Management Behavior: Based on the Comparative Analysis of Salary in Executive Team and between Executives and Employees, Accounting Research, 2014, 06: 57 -65 + 97(In Chinese).

[10] R. Tim and S. Berman, A Brand New Brand of Corporate Social Performance, Business and Society, 2000, Vol. 39 (4): 397-418.

[11] Y. Zhao and Q.G. Feng, Concept of Social Responsibility and Cash Dividend Commitment System - An Empirical Analysis Based on A-share Listed Companies, Economic and Management Research, 2014,05: 58-68(In Chinese).

[12] X.D. Yang and Y.M. Zhang, The Impact of Corporate Governance and Diversification on Corporate Value: Evidence from China's Enterprise Groups, Journal of Business Economics, 2015, 34: 100-103(In Chinese).

[13] X.J. Zhang, J. Xu and L. Guo, Analysis of the Reasons for the Surplus Management of Enterprises, Soft Science, 2004, 05: 85-88(In Chinese).

[14] W.C. Yuan, Earnings management direction and enterprise investment efficiency, Western Forum, 2014, 02: 93-99. (In Chinese).

[15] A.C. Wu, S.D. Luo and W. Wang, Study on Value Relevance and Earnings Management of Security Investment Return, Accounting Research, 2009, 06: 42-49 + 97(In Chinese).

[16] J.X. Geng, Y.J. Lv and X.P. Zou, The Empirical Study on the Long-term Performance of Private Placement in Chinese Listed Companies, Audit \& Economy Research, 2011, 06: 52-58 (In Chinese).

[17] Freeman, E. Edward, Strategic management: A stakeholder approach, Boston: Pitman Publishing Inc, 1984.

[18] Cornell, Shapiro, Corporate social responsibility and financial performance. Financial Management, 1987, 16: 5-14.

[19] T. Donaldson and L.E. Preston, The Stakeholder Theory of the Corporation: Concepts, Evidence and Implications, Academy of Management Review, 1995, Vol. 20 (1): 65-91.

[20] D.W. Su and X.X. He, Social Responsibility and Enterprise Efficiency: Theoretical and Empirical Analysis Based on New Institutional Economics, World Economics, 2011,09: 138-159 (In Chinese).

[21] J. Chen, Corporate social responsibility and corporate performance of the correlation study MS.D, Nanjing University of Finance and Economics, 2010 (In Chinese).

[22] B.J. Yang, Corporate social responsibility, corporate governance and corporate performance, Economic latitude and longitude, 2012, 03: 95-99 (In Chinese).

[23] A. Shleifer, 2004. Does Competition Destroy Ethical Behavior? [R / QL] .Working Paper, Harvard University. Http://papers.ssrn.com/sol3/papers.cfm?abstract_id=495774. 
[24] Shen, $\mathrm{CH}$ and HL Chih. Investor Protection, Prospect Theory, and Earnings Management: An International Comparison of the Banking Industry, Journal of Banking and Finance, 2005, VoI. 29 (10): 2675-2697.

[25] X.Z. Deng and X.M. Liu, Corporate Social Responsibility and Earnings Management: An Empirical Study of Shenzhen A Shares, Journal of Changsha University of Science and Technology (Social Sciences), 2011, 03: 61-65 (In Chinese).

[26] F.S. Wang, S.S. Ji and F. Cheng, Effects of Earnings Management on Future Operating Performance of Listed Companies: A Comparative Perspective Based on Accrual Earnings Management and Real Earnings Management, Nankai Business Review, 2014, 02: 95- 106. (In Chinese).

[27] Y.Y. Zhou and C. Lin, Earnings Management, Social Responsibility and Cash Dividend Tendency, Technical Economics and Management Research, 2015, 12: 67-71 (In Chinese).

[28] A.Y. Zang, Evidence on the trade-off between real activities manipulation and accrual-based earnings management, The Accounting Review, 2012. 87 (2): 675-703. 